\title{
CHARACTERISTICS AND TOXICITY OF NANOEMULSION FORMULATION OF Piper retrofractum AND Tagetes erecta EXTRACT MIXTURES
}

\author{
Ni Siluh Putu Nuryanti ${ }^{1,2}$, Edhi Martono ${ }^{3}$, Endang Sri Ratna ${ }^{4}, \&$ Dadang $^{4}$ \\ ${ }^{1}$ Department of Plant Protection, IPB Graduate School, Bogor Agricultural University, Indonesia \\ Jl. Kamper Kampus IPB Dramaga Bogor 16680 \\ ${ }^{2}$ Department of Food Crops, State Polytechnic of Lampung, Indonesia \\ Jl. Soekarno-Hatta No. 10 Rajabasa Bandar Lampung 35141 \\ ${ }^{3}$ Department of Plant Pests and Diseases, Faculty of Agriculture, Gadjah Mada University, Indonesia \\ Jl. Flora Bulaksumur Yogyakarta 55281 \\ ${ }^{4}$ Department of Plant Protection, Faculty of Agriculture, Bogor Agricultural University, Indonesia \\ Jl. Kamper Kampus IPB Dramaga Bogor 16680 \\ E-mail: siluhputu@gmail.com
}

\begin{abstract}
Characteristics and toxicity of nanoemulsion formulations of Piper retrofractum and Tagetes erecta extract mixtures. Nanotechnology has been used in the developing of botanical insecticide formulation for improving its stability and effectiveness. The research was aimed to make nanoemulsion formulations of Piper retrofractum fruits and Tagetes erecta flowers extracts and to evaluate their toxicity against brown planthopper (Nilaparvata lugens [Stål]) nymphs. The development of nanoemulsion formulaions was carried out by using the low energy method with inversion phase emulsification. The toxicity of the four formulations was tested against brown planthopper nymphs using a contact method. Four nanoemulsion formulations were obtained. The study showed that in the developing of the formulations, the type and level of emulsifier materials affected the physical characteristics of formulas, such as stability, surface tension, viscosity, particle size, and particle morphology. The nanoemulsion formulation containing $1 \%$ of the mixture of P. retrofractum fruits and $T$. erecta flowers extracts, $1.75 \%$ Triton X-100 emulsifier showed the highest toxic on the brown planthopper nymph, with the $\mathrm{LC}_{95} \mathrm{value}$ was $0.15 \%$. The study indicates that nanoemulsion formulation of $P$. retrofractum and $T$. erecta extracts are potential to be developed as botanical insecticide to control brown planthopper of rice.
\end{abstract}

Key words: brown planthopper, nanoemulsion, particle size, surface tension, viscosity

\begin{abstract}
ABSTRAK
Karakteristik dan toksisitas formulasi nanoemulsi insektisida nabati dari campuran ekstrak Piper retrofractum dan Tagetes erecta. Nanoteknologi telah digunakan dalam pengembangan formulasi insektisida nabati untuk meningkatkan stabilitas dan keefektifannya. Penelitian ini bertujuan untuk membuat formulasi nanoemulsi dari ekstrak buah Piper retrofractum dan ekstrak bunga Tagetes erecta dan untuk mengevaluasi toksisitas formulasi nanoemulsi terhadap nimfa wereng batang coklat (Nilaparvata lugens [Stål]). Pengembangan formulasi nanoemulsi dilakukan dengan menggunakan pendekatan metode energi rendah dengan emulsifikasi fase inversi. Toksisitas formulasi diuji terhadap nimfa wereng coklat menggunakan metode kontak. Empat formulasi nanoemulsi diperoleh. Studi ini menunjukkan bahwa dalam pengembangan formulasi, jenis dan konsentrasi bahan pengemulsi mempengaruhi karakteristik fisik formula, seperti stabilitas, tegangan permukaan, viskositas, ukuran partikel, dan morfologi partikel. Formulasi nanoemulsi mengandung 1\% dari campuran buah P. retrofractum dan ekstrak bunga $T$.

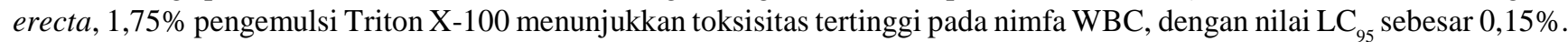
Hasil penelitian menunjukkan bahwa formulasi nanoemulsi ekstrak $P$. retrofractum dan $T$. erecta berpotensi untuk dikembangkan sebagai insektisida nabati untuk mengendalikan WBC padi.
\end{abstract}

Kata kunci: nanoemulsi, tegangan permukaan, ukuran partikel, viskositas, wereng batang cokelat 


\section{INTRODUCTION}

The development of botanical insecticide formulation is an urgent effort to provide an alternative strategy to more environmentally friendly pest control. The main roles of insecticide formulations are to maintain the stability of active materials during distribution and storage, to facilitate product handling and application, to protect the active materials from the adverse environment, and to improve the action of active materials by increasing its contact and interaction to target pest (Gasic \& Tanovic, 2013). Formulation of botanical insecticides followed the same rule as synthetic insecticides consisted of biologically active plant materials such as extracts or essential oils, solvent, diluent, and surfactant (Waxman, 1998). In formulating of botanical insecticides, factors that need to be considered are the type of active material content, ease in handling and mixing, safety risk, target of the application (agricultural, forest, urban), level of effectiveness, behavior of pest, type of appliances for application, risk of laundering or a runoff, phytotoxicity, and production cost (Pimentel, 2005). An accurate selection of the formulation can improve product stability and decrease performance inconsistency of the active materials (Gasic \& Tanovic, 2013).

Nanotechnology has been used in botanical insecticide formulation because it is safer and more effective. According to Tadros et al. (2004), oil nanoemulsion in water $(\mathrm{O} / \mathrm{W})$ is a nanometric size emulsion with 50 to $200 \mathrm{~nm}$ droplet size. The importance of formulating in the nano size of botanical insecticide is it can overcome the low absorbance problem and formulation instability (Carvajal et al., 2010) because tiny little droplets will be broadening the surface area, therefore improve the stability, absorptivity, and purity of the formulation (McClements, 2012). Botanical nano insecticide is expected can reduce the adverse effects on the environment, improve effectiveness, and reduce the cost of pest controlling (Anders \& Glotzer, 2012).

The nanoemulsion can be produced by using two different approaches, i.e. the high- and the low-energy methods. The high energy method utilizes a strong mechanical power to break macroscopic phases or drops into little droplets, usually by using a mechanical device called as a homogenizer, while the low-energy method consists of spontaneous emulsification and inversion phase (McClements \& $\mathrm{Li}, 2010)$. The nanoemulsion production by means of low-energy approach has some advantages, such as ease of application and energy efficient. The components of emulsion formula, such as active ingredients and concentration of emulsifier, determine the successful production of nanoemulsion. Nanoemulsion formulation of neem oil (Azadirachta indica) with emulsifier polysorbate and alkylpolyglucoside was successfully produced using a low-energy method by Choupanian et al. (2017). However, the nanoemulsion production method of botanical insecticide from the mixed extract by using a low-energy method with inversion phase emulsification has not been developed. The mixture of active materials from the plant extract that is nanotechnologically synergetic with emulsification process will minimize the utilization of active materials and improve the biological activity of insecticide.

The extract of $P$. retrofractum fruit was reported to contain insecticidal piperamide compounds, such as guininsin, pelitorin, pipericide, piperin, and retrofractamide A (Scott et al., 2008). These compounds have methylendioxyphenyl groups which can provide synergistic properties when mixed with other insecticidal compounds (Scott et al., 2008). On the other hand, several extracts of Asteraceae plants, such as Gundelia tournefortii, Porophyllum gracile, P. redurale, and Wedelia calendulaceae were also known to have alpha-tertienyl compounds that are synergistic (Baki et al., 2005; Guillet et al., 1998; Ghabeish, 2015). Therefore, the extract mixture of $P$. retrofractum (Piperaceae) and T. erecta (Asteraceae) plants are expected to be compatible and synergetic.

The research was aimed to make nanoemulsion formulation of Piper retrofractum fruits and Tagetes erecta flower extracts and evaluate their toxicity against brown planthopper (Nilaparvata lugens [Stål]) nymphs. The selection of brown planthopper as a target pest because the pest is the most damaging in rice plantation in South-East Asia.

\section{MATERIALS AND METHODS}

Research Site. Extraction and nanoemulsion formulation was carried out at the Laboratory of Insect Physiology and Toxicology, Department of Plant Protection, Faculty of Agricultural, Bogor Agricultural University (IPB). Characterisation of nanoemulsion and morphological analysis of particles was carried out at the Center of Agricultural Postharvest Research and Development, Cimanggu Bogor. The research was performed from September 2016 to May 2017.

Extraction. Plant materials used in this study were $P$. retrofractum fruits (Piperaceae) obtained from Tri Murjo District, Central Lampung Regency (5 ${ }^{\circ} 07^{\prime} 16.86^{\prime \prime S} 105^{\circ} 16^{\prime} 06.08^{\prime \prime} \mathrm{T}, 49 \mathrm{~m}$ above sea level) and 
marigold flowers Tagetes erecta (Asteraceae) from Rajabasah District, Bandar Lampung (5 '22'24.21"S 105 ${ }^{\circ} 14^{\prime} 17.98$ "T). Each plant material was air-dried for 7 to 14 days and powdered using a blender. Every $200 \mathrm{~g}$ of $P$. retrofractum fruits was macerated with $2 \mathrm{~L}$ ethyl acetate (Indriati et al., 2015), while the T. erecta flowers was macerated with ethanol (Sánchez et al., 2012). To get maximal amount of extract with active materials, the mixture of materials and solvent was mixed well, then left for 24 hours, and filtered by using a glass funnel assembled with filter papers. The filtrate was evaporated by using a rotary evaporator at temperature $50{ }^{\circ} \mathrm{C}$ and a pressure at $400-450 \mathrm{~mm} \mathrm{Hg}$ until a crude extract resulted. The extract was stored in a refrigerator at temperature $4{ }^{\circ} \mathrm{C}$ until tested.

Emulsifier Type and Emulsification Method. The nanoemulsion formulation was made by using the lowenergy emulsification method with inversion phase. The emulsification method with inversion phase was performed by using the method of Ostertag et al. (2012) with a slight modification, i.e. adding the water phase into the organic phase little by little. The formulation consisted of a mixture of $P$. retrofractum and $T$. erecta extracts by a ratio of $2: 1$. The solvent and emulsifier were added to each formulation as described in Table 1 .

Both $P$. retrofractum and $T$. erecta extracts were added with an emulsifier and a solvent and then homogenized by using a magnetic stirrer at $750 \mathrm{rpm}$ for 30 minutes. The emulsion formation was carried out by dropping water at a rate of $4 \mathrm{~mL} \mathrm{~min}^{-1}$ while stirred by a magnetic stirrer at $1250 \mathrm{rpm}$ for 60 minutes. The emulsification was performed at a room temperature $\left(<27^{\circ} \mathrm{C}\right)$.
Assessment of Formulation Characteristics. Formulation stability. Formulation stability test was carried out by the standing method (CIPAC, 1980). A test tube $(30 \mathrm{ml})$ was filled with $25 \mathrm{ml}$ of prepared formulation, then the tube was inverted $180^{\circ} 10$ times. Finally, the tube was returned to initial position and placed on a tube rack at room temperature $\left( \pm 27^{\circ} \mathrm{C}\right)$. The color, foam, precipitation, and creaming that was formed after incubated for 1 to 7 days were visually observed.

Surface's Tension. The surface tension of the formulation was determined by using a tensiometer CSC-Dunouy No. 70545 (Sengupta et al., 2016). A scaled-needle was positioned at zero before measurement then the ring balance was set by positioning balance disc forward or backward until the ring handle positioned at zero. The cup filled with liquid or emulsion to be tested was placed on the cup base and raised until reaching the ring. The cup base was then locked by the cup base lock and stopper lock. The cup position was raised by turning the handle up and down until the ring immersed in approximately $0.5 \mathrm{~cm}$ from the surface. The scaled-handle was then turned until the ring removed from the tested material. The handle turning was then stopped and the reading of gram scale measurement result was agreed with the line that equal to the scale needle position. The ring was washed after use before measuring next materials.

Emulsion Viscosity. The measurement of formulation viscosity was performed by using a viscometer model TV-10 TOKI Sangyo Co. Ltd. (Sengupta et al., 2016). The twenty-five $\mathrm{mL}$ sample was added to the container of the viscometer device. The measurement of viscosity was carried out by a spindle M1 at $100 \mathrm{rpm}$. The principle

Table 1. Composition of nanoemulsion formulations tested

\begin{tabular}{llccc}
\hline \multirow{2}{*}{ Formula } & \multicolumn{4}{c}{ Formulation Composition } \\
\cline { 2 - 5 } & Extract Composition $(\%)$ & Emulsifier $(\%)$ & Solvent (\%) & Aquadest (\%) \\
\hline TW1 & $\begin{array}{l}\text { P. retrofractum } 0.67 \\
\text { T. erecta } 0.33\end{array}$ & Tween $80(1.50)$ & Ethanol 3.50 & 94.00 \\
TW2 & $\begin{array}{l}\text { P. retrofractum } 0.67 \\
\text { T. erecta } 0.33\end{array}$ & Tween $80(1.75)$ & Ethanol 3.50 & 93.75 \\
TR1 & $\begin{array}{l}\text { P. retrofractum } 0.67 \\
\text { T. erecta } 0.33\end{array}$ & Triton X-100 (1.50) & Ethanol 3.50 & 94.00 \\
TR2 & P. retrofractum 0.67 & Triton X-100(1.75) & Ethanol 3.50 & 93.75 \\
& T. erecta 0.33 & & & \\
\hline
\end{tabular}


of viscosity determination by the device is to measure resistance, that is caused by the viscosity of certain fluids, that occurred on rotating cylinder or disc in the measured fluid. The result of viscosity measurement was displayed on viscometer screen. Measurement of each formula was performed in three replicates.

\section{Emulsion Droplet Size and Polydispersity Index} (PDI). Droplet size analysis and uniformity of emulsion size were determined by using the particle size analyzer (PSA) (Noor et al., 2015). Three droplets of the sample were diluted with $20 \mathrm{~mL}$ aquadest. The prepared sample was then poured into disposable cuvettes. The cuvettes were placed on object place at position $90^{\circ}$ from a detector. The instrument where the prepared object placed was closed and measurement was carried out by using Zetasizer software with solvent refraction index as data input and laser intensity adjustment. The average droplet size can be read on the measurement result. The droplet size distribution was stated as polydispersity index (PDI).

Morphological Analysis of Emulsion Particle. Visualization of form and morphology of emulsion particles was observed by means of transmission electron microscope (TEM) TECNAI G2 (Burapapadh et al., 2010). The sample was firstly diluted with aquadest by ratio $1: 1(\mathrm{v} / \mathrm{v})$, and then dropped on the $\mathrm{Cu}$ grid disc mesh 400 FormVar carbon, and then left-dried. After drying, the disc was observed under several magnifications (9700-23.000 x) until the morphology of particle droplets was clearly acquired.

Toxicity Assay. The concentrations applied in toxicity assay of formulation was $0.2 \%, 0.1 \%, 0.5 \%, 0.25 \%$, and $0.125 \%$. Those concentrations were determined based on compatibility test between a mixture of $P$. retrofractum and $T$. erecta extracts $(2: 1 ; \mathrm{w} / \mathrm{w})$ conducted before, with acquired $\mathrm{LC}_{95}$ for regular EC formulation was $0.2 \%$ (Nuryanti 2018, unpublished). Ten nymphs of the second instar nymphs of BPH were used in every treatment. The nymphs were put into the plastic tube $(\mathrm{d}=7 \mathrm{~cm}, \mathrm{p}=20 \mathrm{~cm})$. As much $0.4 \mathrm{ml}$ prepared emulsion was sprayed thoroughly into the plastic tube containing the nymphes by using $20 \mathrm{ml}$ hand sprayer. Furthermore, the plastic tube containing nymphs was covered on the rice (21 days after planted) on plastic pots. Every treatment was repeated in 5 replications. The observation was implemented at the $24,48,72$, and
96 hour after treated by calculating nymph mortality percentage. The $\mathrm{LC}_{50}$ and $\mathrm{LC}_{95}$ values were estimated by using probit analysis program POLO-PC (LeOra Software 1987) to determine the correlation of concentration to insect mortality.

\section{RESULTS AND DISCUSSION}

Formulation Stability. The result of formulation stability assay showed that the formula TW1 and TW2 (added with emulsifier Tween-80), produced more clouded yellow colored emulsion than the formula TR1 and TR 2 containing Triton X-100 as an emulsifier. The formula TW1 and TW2 form precipitations on the $7^{\text {th }}$ day, while the TR1 and TR2 formulas were stabled (Table 2; Figure 1). This means that the addition of Triton X-100 as the emulsifier is the best to stabilize the formulas compared to the used of Tween- 80 . The formula stabilization is assumed to be correlated with better surface tension and particle size formation. The smaller particles in the formula, the more stable emulsion formed, therefore, there will not either precipitate nor creaming formed. According to Gupta et al. (2016), one interesting physical characteristic of a nanoemulsion is its transparent properties compared to the nonnanoemulsion one. As stated by Hazra (2017), the nanoemulsion has a particle size less than $200 \mathrm{~nm}$, resulting in transparent properties and more stable movement of particles. Tadros et al. (2004) added some advantages of nanoemulsion application on several products, such as (a) a very small droplet has restraining capacity to gravity and Brownian movement, therefore it prevents precipitate forming and creaming during storage; (b) a small droplet can also avoid flocculation of droplets, allows the system to keep distributed equally and separated; (c) the small droplets also prevents clustering among droplets.

Surface's Tension. The lowest surface tension 32.97 $\pm 0.47 \mathrm{dyne} / \mathrm{cm} 2$ was found at formula TR 2 , while the highest value was found at TW 1 with surface tension $39.03 \pm 0.25$ dynecm $^{-1}$ (Figure 2). It showed that the type of emulsifier affected the surface tension. A lower surface tension will improve the capacity of nanoemulsion to wet and encounter the target. The emulsifier Triton X-100 resulted in lower surface tension than Tween-80. According to Mao et al. (2009), an emulsifier with higher molecular weight has lower absorption kinetics than emulsifier with lower molecular 
Table 2. Stability propertis of nanoemulsion formulations containing a mixture of $P$. retrofractum and T. erecta extracts

\begin{tabular}{|c|c|c|c|c|c|c|c|}
\hline \multirow{2}{*}{ Formula Characters } & \multicolumn{7}{|c|}{ Observation time (day) } \\
\hline & 1 & 2 & 3 & 4 & 5 & 6 & 7 \\
\hline \multicolumn{8}{|l|}{ TW 1} \\
\hline \multirow[t]{2}{*}{ Color } & Yellow & Yellow & Yellow & Yellow & Yellow & Yellow & Yellow \\
\hline & Cloudy & Cloudy & Cloudy & Cloudy & Cloudy & Cloudy & Cloudy \\
\hline Foam & ++ & ++ & + & + & + & + & + \\
\hline Precipitate & - & - & - & - & - & - & + \\
\hline Creaming & - & - & - & - & - & - & - \\
\hline \multicolumn{8}{|l|}{ TW 2} \\
\hline \multirow[t]{2}{*}{ Color } & Yellow & Yellow & Yellow & Yellow & Yellow & Yellow & Yellow \\
\hline & Cloudy & Cloudy & Cloudy & Cloudy & Cloudy & Cloudy & Cloudy \\
\hline Foam & ++ & ++ & + & + & + & + & + \\
\hline Precipitate & - & - & - & - & - & - & + \\
\hline Creaming & - & - & - & - & - & - & - \\
\hline \multicolumn{8}{|l|}{ TR 1} \\
\hline Color & $\begin{array}{l}\text { Clear } \\
\text { yellow }\end{array}$ & $\begin{array}{l}\text { Clear } \\
\text { yellow }\end{array}$ & $\begin{array}{l}\text { Clear } \\
\text { yellow }\end{array}$ & $\begin{array}{l}\text { Clear } \\
\text { yellow }\end{array}$ & $\begin{array}{l}\text { Clear } \\
\text { yellow }\end{array}$ & $\begin{array}{l}\text { Clear } \\
\text { yellow }\end{array}$ & $\begin{array}{l}\text { Clear } \\
\text { yellow }\end{array}$ \\
\hline Foam & +++ & +++ & ++ & ++ & + & + & + \\
\hline Precipitate & - & - & - & - & - & - & - \\
\hline Creaming & - & - & - & - & - & - & - \\
\hline \multicolumn{8}{|l|}{ TR 2} \\
\hline Color & $\begin{array}{l}\text { Clear } \\
\text { yellow }\end{array}$ & $\begin{array}{l}\text { Clear } \\
\text { yellow }\end{array}$ & $\begin{array}{l}\text { Clear } \\
\text { yellow }\end{array}$ & $\begin{array}{l}\text { Clear } \\
\text { yellow }\end{array}$ & $\begin{array}{l}\text { Clear } \\
\text { yellow }\end{array}$ & $\begin{array}{l}\text { Clear } \\
\text { yellow }\end{array}$ & $\begin{array}{l}\text { Clear } \\
\text { yellow }\end{array}$ \\
\hline Foam & +++ & +++ & ++ & ++ & + & + & + \\
\hline Precipitate & - & - & - & - & - & - & - \\
\hline Creaming & - & - & - & - & - & - & - \\
\hline
\end{tabular}

Criteria of formula character: +++: high, ++: moderate, + : low, -: none.

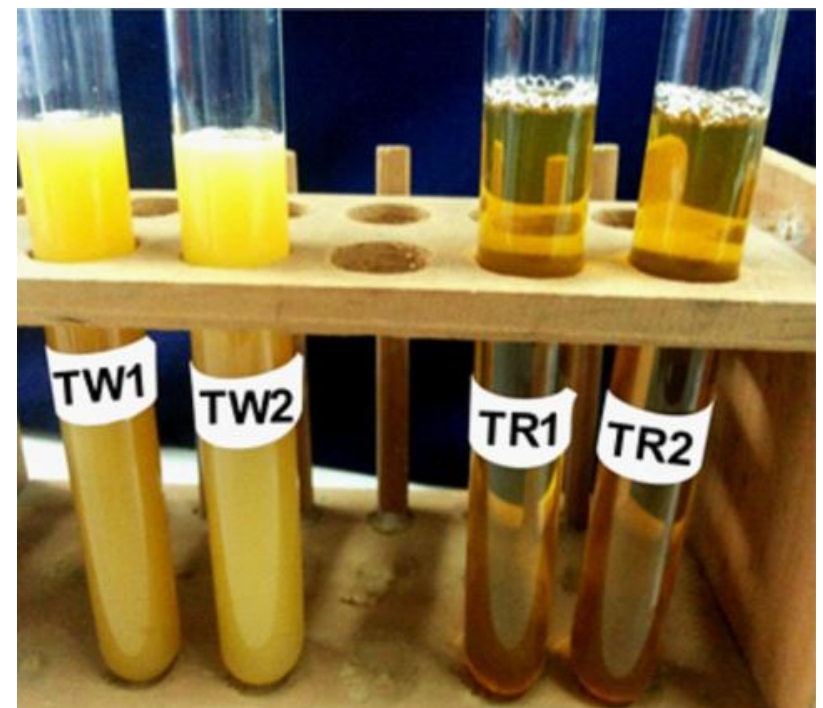

Figure 1. Physical appearances of nanoemulsion formulas containing a mixture of P. retrofractum and $T$. erecta extracts. 
weight. Tween 80 has higher molecular weight than Triton X-100. It is known that molecular weight of Tween-80 is $1.310 \mathrm{~g} \mathrm{~mol}^{-1}$, while Triton $\mathrm{X}-100$ 's molecular weight is $1.061 \mathrm{~g} \mathrm{~mol}^{-1}$ (Ostertag et al., 2012). Corresponding to its function, the surfactant has the role to stabilize formula by lowering surface tension and forming protection layer covering dispersed globular phase, hence the non-dissolved compounds will more easily be dispersed in the system and stabilized. As stated by Manglik et al. (2001), basically, a surfactant is a chemical compound with low molecular weight. The compound has a combination of the hydrophilic group which is attracted to water and a hydrophobic group which repels water. Surfactant addition will rapidly cover the oil-water interphase during emulsification, hence lower the surface tension. The result expected is to more expanded contact with the target.
Emulsion Viscosity. The highest viscosity of the four formulations measured was found in formula TR2 with viscosity $4.86 \pm 0.5 \mathrm{cP}$, and the lowest value was found in formula TW1 with viscosity $3.76 \pm 0.10 \mathrm{cP}$ (Figure 3 ). A viscosity represents the resistance of a material to flow due to friction or response to formation changes when subjected to a certain force (Toledo, 2007). The viscosity of nanoemulsion was observed to improve along with increasing concentration of emulsifier. According to Perazzo et al. (2015), the increase of liquid viscosity will increase the time needed by a liquid to flow, hence lowering the coalescence level due to larger ambivalence. Emulsion addition caused a reduction in droplet size at dispersed phase, which is causing an increment in viscosity (Sanjeewani \& Sakeena, 2013). The emulsion viscosity that was increased with an increment of surfactant concentration in spontaneous emulsification was also reported by Sugumar et al. (2015).

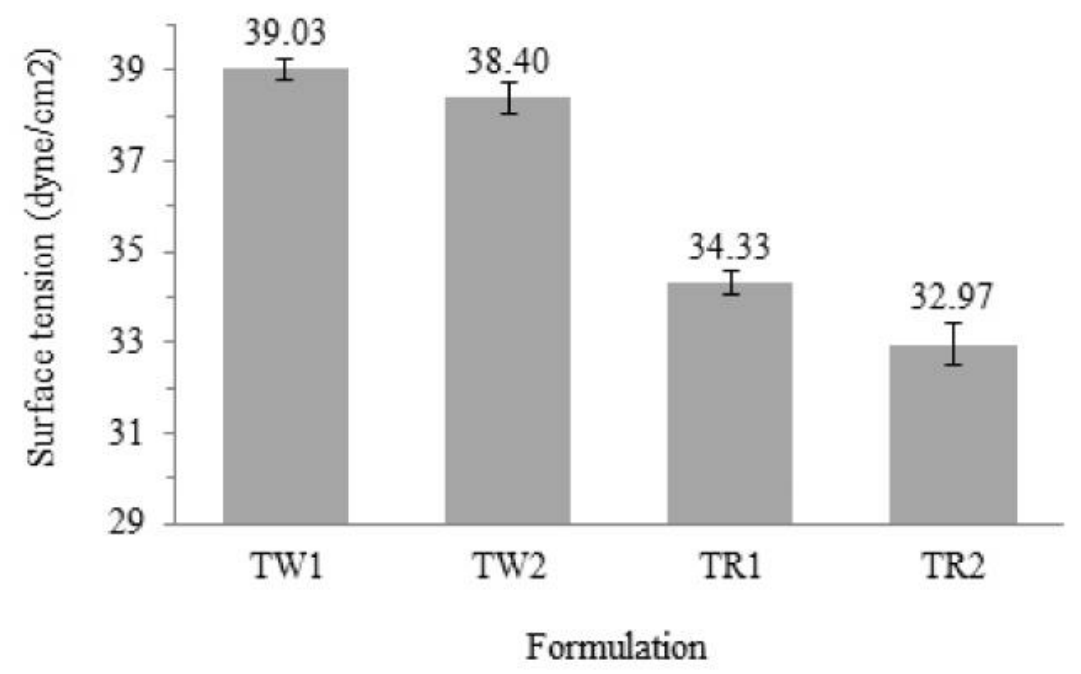

Figure 2. Surface tension of the four botanical insecticide nanoemulsion formulations containing a mixture of $P$. retrofractum and $T$. erecta extracts.

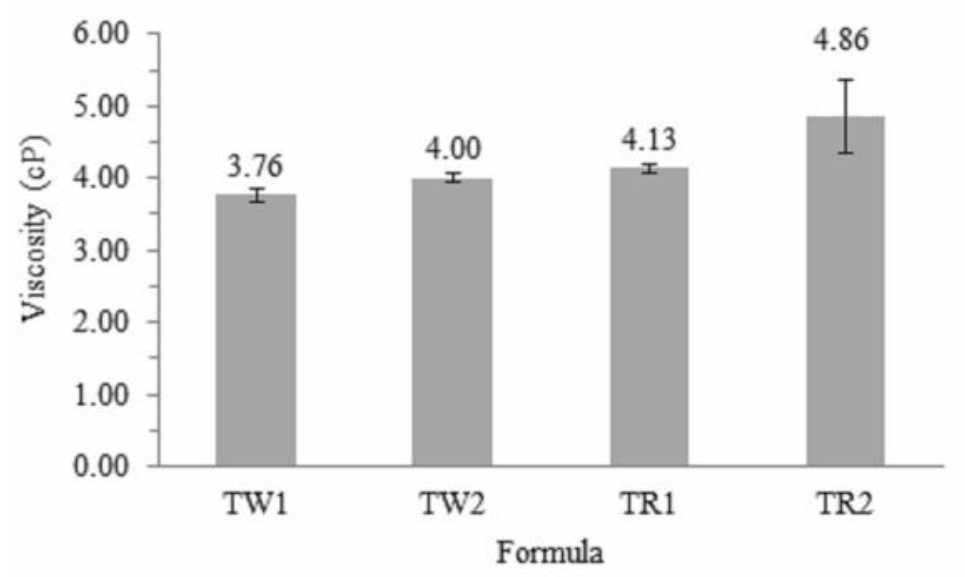

Figure 3. Viscosity of four nanoemulsion formulations containing a mixture of P. retrofractum and T. erecta extracts. 
Emulsion Particle Size. Particle size is an important indicator used in determining emulsion stability (Ibrahim et al., 2015). The emulsion particle size in the TR2 formula was the lowest, that was $80.41 \pm 1.67 \mathrm{~nm}$, and the highest size was found in TW1 formula, $143.80 \pm$ $1.65 \mathrm{~nm}$ (Figure 4). The four formulations resulted are categorized as nanoemulsion. El-Said et al. (2015) stated that nanoemulsion is an emulsion with droplet size from 20 to $200 \mathrm{~nm}$. In the application of both emulsifier (Tween 80 and Triton X-100) showed that the increment in emulsifier concentration affected to a particle size of emulsion resulted. The higher concentration of emulsifier, the smaller droplet size resulted. Anjani et al. (2012) reported that the droplet size influenced formulation activity. According to Ghosh et al. (2013), surfactant concentration has an important role in determining the size of nanoemulsion droplet, that is the increment in surfactant concentration causes reduction in droplet diameter. The increment of surfactant concentration in emulsification of virgin coconut oil also decreased the size of nanoemulsion droplet (Sanjeewani \& Sakeena, 2013). Furthermore, Choupanian et al. (2017) reported that neem oil formulation with the addition of more than $1.5 x$ polysorbate and alkylpolyglucoside as emulsifier can decrease the particle size less than $100 \mathrm{~nm}$.

Polydispersity Index. The lowest polydispersity index (PDI) among four formulas was found at the TR2 formula, that is $0.297 \pm 0.033$, and the highest index was at TW1, that is $0.424 \pm 0.09$ (Figure 5). It shows that the Triton X-100 emulsifier is better than Tween 80 in resulting uniform droplets. The PDI of the emulsion is a

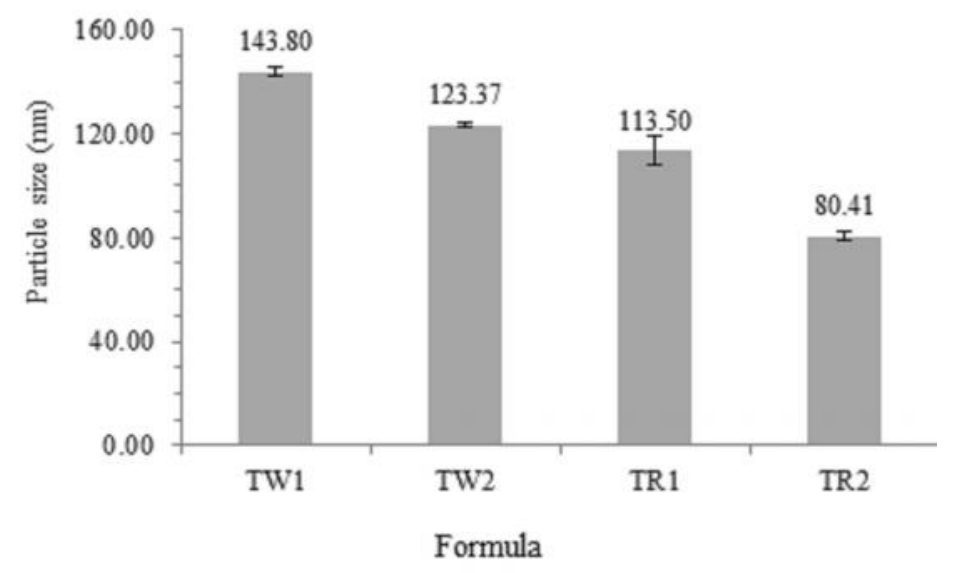

Figure 4. Emulsion particle size of four nanoemulsion formulations containing a mixture of P. retrofractum and T. erecta extracts.

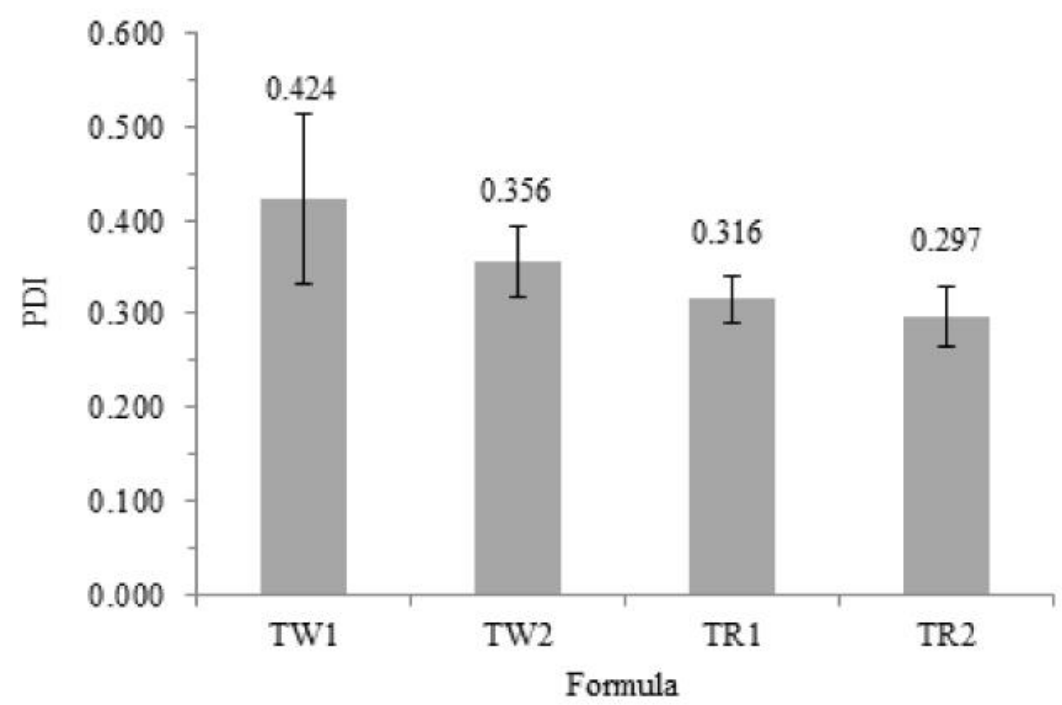

Figure 5. Polydispersity Index (PDI) of four nanoemulsion formulations containing a mixture of $P$. retrofractum and $T$. erecta extracts. 
parameter that represents droplet size uniformity in emulsion system (Piorkowski \& McClements, 2014). According to Wu et al. (2012), if an emulsion has PDI $<0.3$ then the emulsion system has a good particle uniformity. The lower PDI value of an emulsion, the more uniform size distribution of emulsion droplet.

Morphology of Emulsion Droplet. Morphological characteristics of the droplet by TEM at magnification 23.000x showed that Triton X-100 (both in TR1 and TR2) resulted in a smaller droplet size and more equal distribution (Figure 6).

Toxicity of Four Botanical Insecticide Formulations on Brown Planthopper. The result of probit analysis on the four nanoemulsion formula of P.retrofractum and T. erecta extract mixture on brown planthopper nymph at 96 hours after treatment indicated the lowest $\mathrm{LC}_{50}$ $0.05 \%$, both at TR1 and TR2, followed by TW2 and TW1 formula with $\mathrm{LC}_{50} 0.07 \%$ and $0.10 \%$, respectively. The $\mathrm{LC}_{95}$ value indicated the same trend, however, the lowest $\mathrm{LC}_{95} 0.15 \%$ resulted in TR2 formula (Table 3 ). Therefore, the TR2 formula was the most toxic compared to the other formulations.

Beside of the surface tension and viscosity, the higher toxicity in TR2 formula compared to other formulas was also predicted to be related to particle size. The smaller particle size, the more efficient the active component to contact with the target, because the larger surface area of emulsion will enhance its distribution and penetration (Thakur et al. 2012). Based on particle size observation, the TR2 formula was observed to have the smallest particle compared to the other formula. According to Peter et al. (2014), the

Table 3. Probit regression parameter prediction on the correlation of concentration of nanoemulsion formulas containing a mixture of $P$. retrofractum and $T$. erecta extracts to the mortality of brown panthopper nymphs observed at 96 hours after the treatment

\begin{tabular}{lrrcc}
\hline Formula & $a \pm \mathrm{GB}$ & $b \pm \mathrm{GB}$ & $\begin{array}{c}\mathrm{LC}_{50} \\
(\mathrm{SK} 95 \%)(\%)\end{array}$ & $\begin{array}{c}\mathrm{LC}_{95} \\
(\mathrm{SK} 95 \%)(\%)\end{array}$ \\
\hline TW1 & $2.88 \pm 0.36$ & $2.89 \pm 0.39$ & $0.10(0.06-0.13)$ & $0.37(0.24-1.33)$ \\
TW2 & $3.65 \pm 0.43$ & $3.30 \pm 0.44$ & $0.07(0.03-0.11)$ & $0.25(0.16-1.22)$ \\
TR1 & $4.29 \pm 0.54$ & $3.35 \pm 0.47$ & $0.05(0.02-0.07)$ & $0.16(0.11-0.92)$ \\
TR2 & $4.49 \pm 0.55$ & $3.48 \pm 0.49$ & $0.05(0.02-0.07)$ & $0.15(0.11-0.51)$ \\
\hline
\end{tabular}

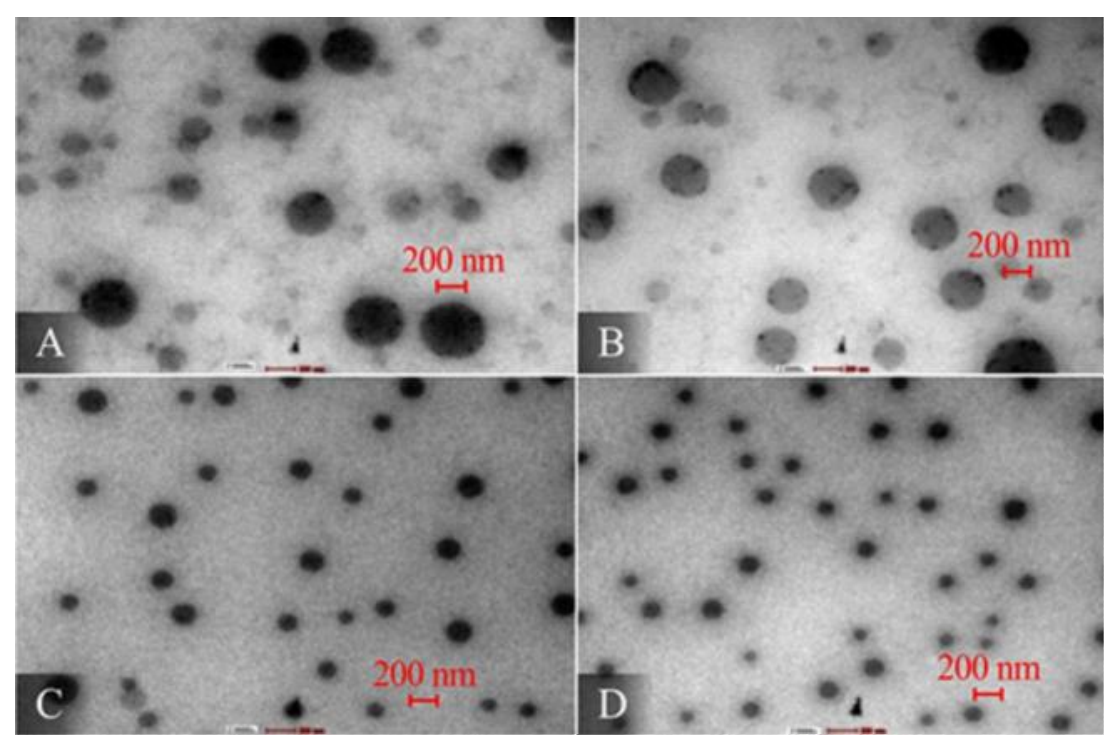

Figure 6. Droplet morphology of four nanoemulsion formulations containing a mixture of P. retrofractum and T. erecta extracts observed with a TEM with $23.000 \mathrm{x}$ magnification $(\mathrm{A}=\mathrm{TW} 1 ; \mathrm{B}=\mathrm{TW} 2 ; \mathrm{C}=\mathrm{TR} 1$; $\mathrm{D}=\mathrm{TR} 2)$. 
advantage provided by nanotechnology includes the unique functional properties of its particles, that is nanoparticle size with the much larger surface area and higher mass than those of non-nanomaterial, therefore it allows bigger chance to contact and penetrate the target. Hence, it can improve the efficacy and effectivity of the active compounds. Vinutha et al. (2013) added more advantages of nanoparticle use, that it give slow release effect, hence it can extend the shelf-life.

The correlation of particle diameter to particle number, and particle diameter to particle surface area volume $^{-1}$ has two important implication to nanoformulation behavior. First, smaller nanoparticles can increase the potential to the disposition to multiple and different locations. Second, the surface area volume${ }^{1}$ ratio is higher for smaller particles, and it is conducive for larger chemical reaction because there are the bigger proportion of atoms on the particle surface (APVMA, 2015).

The formulation containing a mixture of $P$. retrofractum and $T$. erecta extracts in a nanoemulsion form can also increase the extract activity, hence it will improve the safety aspect to the developed prominent plants. In nanoemulsion formulation, the biological performance of the active material of botanical insecticide is improved by using surfactant and additives (Chhipa 2017). The nanoemulsion formula will reduce drifting and active material washing when being applied, therefore it will more precisely hit the target and endure longer in the environment (Margulis-Goshen \& Magdassi 2012)

Choupanian et al. (2017) stated that with nanoformulation, the botanical insecticide can overcome oxidative reaction and polymerization causing declining effectivity. The nanoemulsion formulation has other advantages, such as improving stability, decreasing leaching and drifting due to its solid property, enhancing solubility, releasing active material slowly, and protecting to active material early degradation (Margulis-Goshen \& Magdassi 2012; Ragaei \& Sabry 2014). The nanoemulsion method has been applied to make botanical insecticide formulations, such as nanoformulation of jojoba oil that showed an insecticidal activity to Sitophilus oryzae (Aboelkassem et al., 2015), nanoformulation of Eucalyptus oil for controlling Pectinophora gossypiella and Earias insulana larva (Moustafa et al., 2015), and nanoformulation of essential oil of Ocimum sanctum to control Aedes aepyti and Culex quinquefasciatus (Ramar et al., 2017). Noveriza et al. (2017) described that the application of nanoemulsion lemon grass oil at concentration $1.5 \%$ repressed $77.92 \%$ Potyvirus (the virus causing mosaic disease in patchouli plants), better than the none one. It indicates that the nanoemulsion formulation of botanical insecticides is prospective to be developed for plant pest control.

\section{CONCLUSION}

Four nanoemulsion formulations containing a mixture of $P$. retrofractum fruits and $T$. erecta flowers extracts, Tween-80 and Triton X-100 emulsifiers have been produced with the low-energy emulsification technique with inversion phase. One of the formulations produced (TR2) showed the best performance in all physical formulation characters, including the stability, surface tension, viscosity, particle size, polydispersity index, and emulsion droplet morphology. This nanoemulsion formulation was the highest toxicity $\left(\mathrm{LC}_{95}\right.$ $=0.15 \%)$ to brown planthopper nymph.

\section{ACKNOWLEDGMENTS}

The research was supported by a BPPDN Scholarship fund provided by the Ministry of Research, Technology and Higher Education (Kemenristek Dikti) Republic of Indonesia, 2014-2018. Also, we would thank to Ir Djoko Prijono, M.Agr.Sc. as Head of Insect Physiology and Toxicology Laboratory, Department of Plant Protection, Agricultural Faculty IPB for his supports during research implementation.

\section{REFERENCES}

Aboelkassem SH, Abdelrazeik AB, \& Rakha OM. 2015. Nanoemulsion of jojoba oil, preparation, characterization and insecticidal activity against Sitophilus oryzae (Coleoptera: Curculionidae) on wheat. IJAIR. 4(1): 319-1473.

Anders GV \& Glotzer SC. 2012. DNA nSanotechnology: the world's smallest assembly line. Nat. Chem. 4: 79-80.

Anjani CH, Sharma Y, Mukherjee A, \& Chandrasekaran N. 2012. Neem oil (Azadirachta indica) nanoemulsion: a potent larvacidal agent against Culex quinquefasciatus. Pest. Manag. Sci. 68(2): 158-163.

[APVMA] The Australian Pesticides and Veterinary Medicines Authority. 2015. Nanotechnologies for Pesticides and Veterinary Medicines: Regulatory Considerations. Final report by the Australian Pesticides and Veterinary Medicines Authority (APVMA). APVMA, Kingston. 
Baki MA, Akhtar N, Rahman MM, Islam MN, Hossain M, Islam N, Alam MK, Islam R, Khatum NA, \& Mondal KAMSH. 2005. Synergistic action of Wedelia calendulaceae Less. plant extracts with lamda cyhalothrin on adult red folur beetle Tribolium castaneum Herbst. J. Agron. 4: 1822.

Burapapadh K, Kumpugdee-Vollrath M, Chantasart D, \& Sriamornsak P. 2010. Fabrication of pectinbased nanoemulsions loaded with itraconazole for pharmaceutical application. Carbohydr. Polym. 82: 384-393.

Carvajal MXQ, Diaz BHC, Torres LSM, Perez JJC, Beltran LA, Aparicio AJ, \& Lopez GFG. 2010. Nanoencapsulation: a new trend in food engineering processing. Food Eng. Rev. 2: 3950 .

Chhipa H. 2017. Nanopesticide: current status and future possibilities. Agric. Res. Technol. 5(1): 1-4.

Choupanian M, Omar D, Basri M, \& Asib N. 2017. Preparation and characterization of neem oil nanoemulsion formulations against Sitophilus oryzae and Tribolium castaneum adults. J. Pestic. Sci. 42(4): 158-165.

[CIPAC] Collaborative International Pesticides Analytical Council. 1980. Handbook Analysis of Technical and Formulated Pesticides. CIPAC, New York.

El-Said N, Kassem AT, \& Aly HF. 2015. Nanoemulsion for nanotechnology, size-controlled synthesis of Pd (II) nanoparticles via nano emulsion liquid membrane. Nano Tech Nano Sci Ind J. 9(2): $81-88$.

Finney DJ. 1971. Probit Analysis. $3^{\text {rd }}$ ed. Cambridge Univ Pr, Cambridge.

Gasic S \& Tanovic B. 2013. Biopesticide formulations: possibility of application and future trends. $J$. Pestic. Phytomed. 28(2): 97-102.

Ghabeish IH. 2015. Insecticidal activity and synergistic effect of Gundelia tournefortii L. (Asteraceae: Compositae) extracts and some pure constitutents on Drosophila melanogaster Meogen (Drosophilidae: Diptera). Jordan J. Agric. Sci. 11: 353-366.

Ghosh V, Saranya S, Mukherjee A, \& Chandrasekaran N. 2013. Cinnamon oil nanoemulsion formulation by ultrasonic emulsification: investigation of its bactericidal activity. J. Nanosci. Nanotechnol. 13: $114-122$.

Guillet G, Belanger A, \& Arnason JT. 1998. Volatile monoterpenes in Porophyllum gracile and $P$. ruderale (Asteraceae): identification, localization and insecticidal synergism with $\alpha$-terthienyl. Phytochemistry. 49: 423-429.

Gupta A, Eral HB, Hatton TA, \& Doyle PS. 2016. Nanoemulsions: formation, properties and applications. Soft Matter. 12(11): 2826-2841.

Hazra DK. 2017. Nano-formulations: high definition liquid engineering of pesticide for advanced crop protection in agriculture. Adv. Plant. Agric. Res. 6(3): 1-2.

Ibrahim N, Raman IA, \& Yusop MR. 2015. Effects of functional group of non-ionic surfactants on the stability of emulsion. Malay. J. Anal. Sci. 19(1): 261-267.

Indriati G, Dadang, \& Prijono D. 2015. Insecticidal activity of Piper retrofractum fruit extract on Helopeltis antonii (Hemiptera: Miridae) (In bahasa Indonesia). J. Littri. 21(1): 33-40.

LeOra Software. 1987. POLO-PC User's Guide. LeOra Software, Petaluma, California.

Manglik RM, Wasekar VM, \& Zhang J. 2001. Dynamic and equilibrium surface tension of aqueous surfactant and polymeric solutions. Exp. Therm. Fluid Sci. 25: 55-64.

Mao L, Xu D, Yang J, Yuan F, GaoY, \& Zhao J. 2009. Effects of small and large molecule emulsifiers on the characteristics of $\beta$-carotene nanoemulsions prepared by high pressure homogenization. Food Technol. Biotechnol. 47: 336-342.

Margulis-Goshen K \& Magdassi S. 2012. Nanotechnology: an advance approach to the development of potent insecticides. In: Ishaaya I, Horowitz AR, \& Paili SR (Eds.). Adv. Technol. Manag. Insect Pests. pp. 295-314. Springer, Dordrecht.

McClements DJ. 2012. Nanoemulsions versus microemulsions: terminology, differences and similarities. Soft Matter. 8: 1719-1729.

McClements DJ \& Li Y. 2010. Structured emulsion-based delivery systems: controlling the digestion and release of lipophilic food components. $A d v$. Colloid Interface Sci. 159(2): 213-228. 
Moustafa HZ, Mohamad TGM, \& Turkey H. 2015. Effect of formulated nenoemulsion of Eucalyptus oil on the cotton bollworms. J. Biol. Chem. Res. 33: $478-484$.

Noor E, Harmi L, Maddu A, \& Yusron M. 2015. Fabrication of nanogingerol by combining phase inversion composition and temperature. Res. $J$. Pharm. Biol. Chem. Sci. 6(1): 38-47.

Noveriza R, Mariana M, \& Yuliani, S. 2017. Keefektifan formula nanoemulsi minyak serai wangi terhadap potyvirus penyebab penyakit mosaik pada tanaman nilam. Bul. Penel. Tan. Rempah Obat. 28: $47-56$.

Ostertag F, Weiss J, \& McClements DJ. 2012. Lowenergy formation of edible nanoemulsions: factor influencing droplet size produced by emulsion phase inversion. JCIS. 388(1): 95-102.

Perazzo A, Preziosi V, \& Guido S. 2015. Phase inversion emulsification: current understanding and applications. Adv. Colloid Interface Sci. 222: 581-599.

Peters R, Brandhoff $\mathrm{P}$, Weigel S, Marvin H, Bouwmeester H, Aschberger K, Rauscher H, Amenta V, Arena M, Moniz FB, Gottardo S, \& Mech A. 2014. Inventory of Nanotechnology applications in the agricultual, feed and food sector. EFSA Supporting Publication 2014 EN621.

Pimentel D. 2005. Environmental and economic costs of the application of pesticides primarily in the United States. Environ. Devel. Sustain. 7(2): 229-252.

Piorkowski DT \& McClements DJ. 2014. Beverage emulsions: recent developments in formulation, production and applications. Food Hydrocoll. 42: $5-41$.

Ragaei M \& Sabry AKH. 2014. Nanotechnology for insect pest control. Int. J. Sci. Environ. Technol. 3(2): 528-545.

Ramar M, Manonmani P, Arumugam P, Kannam SK, Erusan RR, Baskaran N, \& Murugan K. 2017. Nano-insecticidal formulations from essential oil (Ocimum sanctum) and fabricated in filter paper on adult of Aedes aegypti and Culex quinquefasciatus. J. Entomol. Zool. Stud. 5: 1769-1774.
Sánchez DOS, Llanos LA, Estrada MEV, Ochoa MG, Cisnero GV, \& Flores ER. 2012. Insecticidal activity of Tagetes erecta extracts on Spodoptera frugiperda (Lepidoptera: Noctuidae). Florida Entomol. 95(2): 428-432.

Sanjeewani NA \& Sakeena MHF. 2013. Formulation and characterterization of virgin coconut oil based emulsion. IJSRP. 3(12): 1-6.

Scott IM, Jensen H, Philogene BJR, \& Arnason JT. 2008. A review of Piper spp. (Piperaceae) phytochemistry, insecticidal activity and mode of action. Phytochem Rev. 7: 65-75.

Sengupta S, Banerjee S, Sinha B, \& Mukherjee B. 2016. Improved skin penetration using in situ nanoparticulate diclofenac diethylamine in hydrogel systems: in vitro and in vivo studies. AAPS Pharm. SciTech. 17(2): 307-317.

Sugumar S, Mukherjee A, \& Chandrasekaran N. 2015. Nanoemulsion formation and characterization by spontaneous emulsification: investigation of its antibacterial effects on Listeria monocytogenes. Asian J. Pharm. 9(1): 23-28.

Tadros T, Izquierdo P, Esquena J, \& Solans C. 2004. Formation and stability of nano-emulsions. $A d v$. Colloid Interface Sci. 108: 303-318.

Thakur N, Garg G, Sharma PK, \& Kumar N. 2012. Nanoemulsions: a review on various pharmaceutical application. Glob. J. Pharmacol. 6: 222-225.

Toledo RT. 2007. Fundamentals of Food Process Engineering. $3^{\text {rd }}$ ed. Springer, New York.

Vinutha JS, Bhagat D, \& Bakthavatsalam N. 2013. Nanotechnology in the management of polyphagous pest Helicoverpa armigera. $J$. Acad. Indus. Res. 1(10): 606-608.

Waxman MF. 1998. Agrochemical and Pesciticide Safety Handbook. Lewis, Boca Raton.

Wu Y, Luo Y, \& Wang Q. 2012. Antioxidant and antimicrobial properties of essential oils encapsulated in zein nanoparticles prepared by liquid-liquid dispersion method. LWT-Food Sci. Technol. 48: 283-290. 